\title{
HOW CAN INFORMATION DESIGNERS ENHANCE LEARNING?
}

\author{
Julia Castillo, MA. \\ University of Reading \\ castillo.maju@gmail.com
}

\begin{abstract}
E-learning, user-centred, design techniques
This paper intends to gather information from the cognitive sciences, psychology and behavioural sciences to understand how to enhance learning through design in the instruction. A matrix of which design techniques can be used to achieve e-learning goals at different levels is the result of this work.
\end{abstract}

\section{Introduction}

E-learning has opened many doors to expand education; some education philosophers like Ivan Illich envisioned education being enhanced by the internet and technology. These ideas are behind projects like One Laptop per Child - a non-profit project where kids from developing countries receive a computer to empower them in their education (One laptop per child, 2016). This enthusiasm, shared by many educators, has created different strategies whose objective is to enhance learning using technology. Virtual classrooms, video tutorials, online communities, augmented reality applications and e-Books, to mention just a few, are some new tools focused on supporting learning.

In the past decades, e-learning was expected to be more efficient than live teachers or other medialike books or television. It was also expected to be more motivating, to accommodate various learning styles maximising learning, and to give autonomy and control to students (Clark \& Mayer, 2011). However, e-learning success is not guaranteed, as any other innovation, it is related to good practices, research and appropriation.

E-learning did not reach its expected growth at the beginning of the century (Mason \& Rennie, 2006). However, its usage is still rising (Clark \& Mayer, 2011) and there are many good examples and projects around the world. It is present in govern- ments' agendas because technology-assisted education has proven beneficial for primary schools as well as for higher education and distance learning (Byrne \& Sharp, 2015; Peters, 2014).

Nevertheless, to achieve the full potential of technology in education more research and studies are needed (Clark \& Mayer, 2011). Clark \& Mayer (2011), Hsi \& Soloway (1998), as well as Peters (2014), have emphasised the importance of a learner-centred approach. They prioritise the design of this technology in a different way to finally address the distinctive needs of learners.

E-learning has many elements to consider but this work with focus on exposition. Learning or teaching has many layers such as the interaction between learner and teacher, between students, with the learning material, our previous ideas, and with technology - with the technological interface itself. Exposition is just one part of e-learning environments, and it is related with the delivery of information to learners. It is mainly a one-way interaction but it might include the participation of the learner with questions, by choosing the content as well as the form and time that exposition takes. Learners can interact with the information in many ways (Hubbard, 2013). The instructional material is the form that the exposition takes, and in e-learning, it is sometimes called multimedia learning material because it naturally takes advantage of different media. Namely, images, text, audio, animations, or video, when used together, are proven 


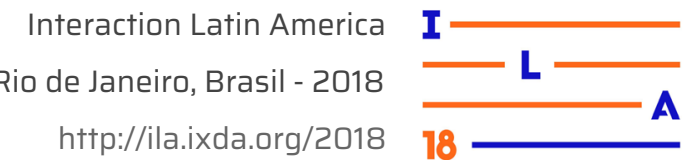

to be more efficient than using only words or images (Mayer, 2014).

This paper focuses on how to present information for e-learning. Designers can incorporate the knowledge generated by the cognitive sciences, psychology and behavioural sciences -the educational sciences- as a valuable input to design e-learning instruction. Specifically, this project is intended to gather all the relevant matters to understand and analyse how to enhance learning through design.

A literature review about how we learn and how the educational sciences propose to enhance e-learning is confronted with information design knowledge.

The result of this paper is a table that summarises the strategies to enhance learning and how to achieve them through design techniques, which could be useful to other designers interested in addressing the learner's needs.

\section{Understanding e-learning}

The first step to being able to address learners' needs is to know how we learn. There are three aspects related to it: acquisition of knowledge, memory's limitations, and motivation (Mayer, 2014).

\subsection{Knowledge acquisition}

To understand how knowledge is acquired, cognitive sciences divide the process into four stages:

-Selecting words

-Selecting images

-Organizing words

-Organizing images

Figure 1. A cognitive theory of multimedia learning. (Adapted from Clark \& Mayer, 2011).
The diagram in Figure 1 illustrates the process of learning and demonstrates it is an active one. The diagram also shows that learning takes place through two channels: a verbal and a non-verbal. Moreover, it shows the importance of memory and prior knowledge for making the connections that will construct the knowledge. Furthermore, it implies the potential importance of graphic designers' role in instructional design as creators for the visual channel principally.

To put it more simple, the learning process has three main steps: the perception of information through words and pictures (the two channels), the organisation of that information, and then the integration of it in our prior knowledge. Once those steps are achieved the learner should be able to retrieve that information. This process is summarised in Figure 2.

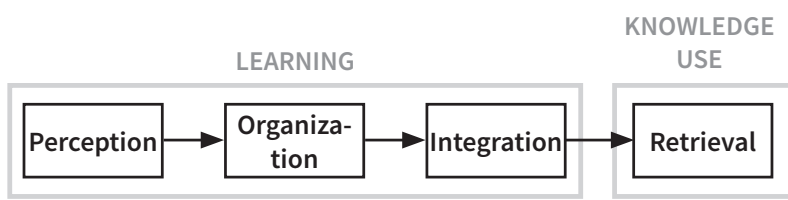

Figure 2. The learning process.

Therefore, the three aspects involved in knowledge acquisition introduced in this section are: The information processing system studied by cognitive theories that explains the process of perceiving information. The memory system studied by psychological sciences that represents the limitations of the mind. And the motivation, studied by behavioural sciences to engage learners in active learning.

We can relate each of these aspects to a stage in the learning process. As shown in figure 3, the perception of information is related to our senses. In e-learning, the senses involved are our vision and our audition. To organize information we need to use our working memory. Further, our motivation will determine the integration of that information. Finally, to be able to retrieve that information our






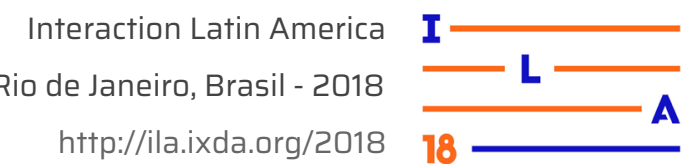

long-term memory will be involved.

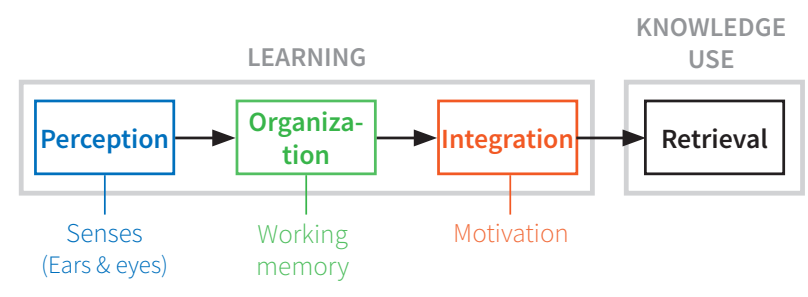

Figure 3. Learning process implications by stage.

\subsection{Memory limitations}

The cognitive sciences understand that our mind has a limited capacity in memory and attention (Mayer, 2012). This result in demands in each of the learning steps, the three demands of our cognitive capacity that take an important place in learning are:

"Extraneous processing-is cognitive processing that does not support the instructional objective and is created by poor instructional layout (such as having a lot of extraneous text and pictures); Essential processing - is cognitive processing aimed at mentally representing the core material (consisting mainly of selecting the relevant material) and is created by the inherent complexity of the material; and

Generative processing - is cognitive processing aimed at deeper understanding of the core material (consisting mainly of organizing and integrating) and is created by the motivation of the learner to make sense of the material." (Clark \& Mayer, 2011, p. 37).

\subsection{The role of motivation}

Motivation takes an important role because learning is an emotional activity (Hsi \& Soloway, 1998; Norman \& Spohrer, 1996). This means that the engagement with learning will condition the learners' attention and their actual knowledge integration. Deci and Rayan (1975) claim that motivation could be intrinsic or extrinsic. Intrinsic motivation is related to naturally enjoyable activities, and extrinsic motivation relates to doing something that will achieve a separate outcome (as cited in Peters, 2014). Peters (2014) argues that despite both are important, extrinsic motivation has some limitations. For this reason, it is always better to try to reach intrinsic motivation that can be related to human beings' motivators, such as autonomy, mastery, competence, connectedness and purpose, among others.

\subsection{Multi-modality and designers' role}

Language is essential for the communication of information. As Michael Twymans (1985) reflects, different disciplines understand language with different approaches: for linguistics, language is either spoken or written, whereas for graphic designers it is pictorial or verbal. When designers work with the visual world, it is not only with the pictorial and schematics visuals but also with the graphic representation of verbal language. Furthermore, they work with the relation between them too. The following diagram is an attempt to represent the different approaches to language.

Figure 4 . An attempt by Twyman to accommodate the

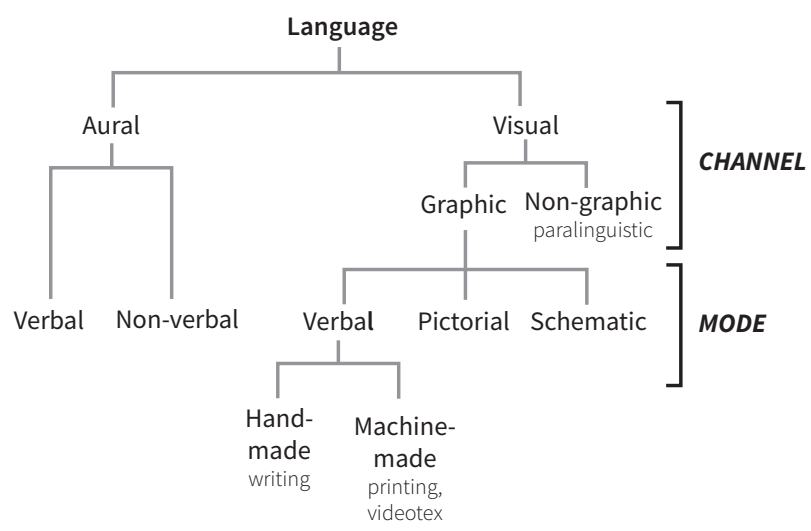

different approaches to language (adapted from Twyman, 1985).

Multi-modality is about using more than one mode to deliver a message. E-learning is strongly associated with multimedia, sometimes even 'multimedia environment' is used as a synonym for 'e-learning environment'. This could be due to the easy integration of text, graphics, sound, video or animations provided by technology. This integration is called by semiotics the use of multiple modes (Jewitt \& Kress, 2008).

Table 1. Multimedia classification.

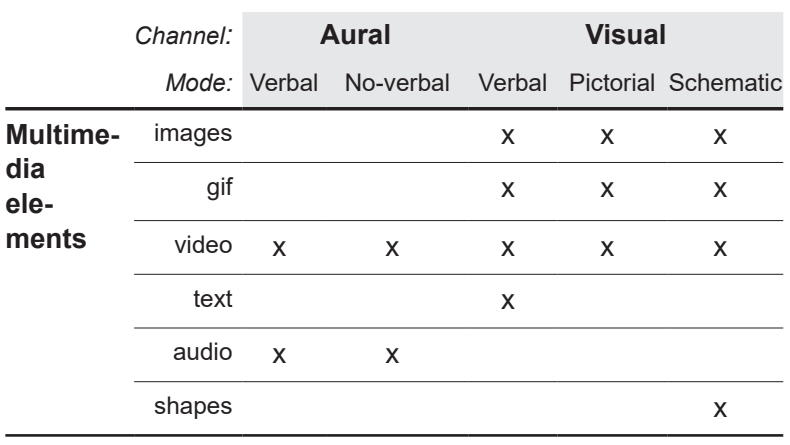




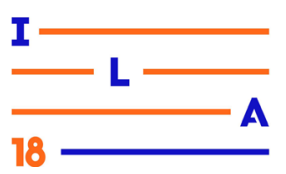

Multi-modality has proven to be more efficient than just using one mode for delivering information (Clark \& Mayer, 2011). While in digital devices multi-modality is implemented by multimedia material, traditionally in schools multi-modal communication was always provided by teachers, who beside their voice they adapt postures, make gestures or use instructional materials such as images, posters or books (González \& Salsamendi, 2016).

Designers have a particular interest in multi-modality; graphic designers especially in graphic multi-modality as this is their subject matter. Many authors have described the power of images and the importance of the relationship of them with text or other modes to deliver effective messages (Hartley, 1994; Neurath, 1936; Twyman, 1979; Waller, 1985). This specialisation makes designers useful professionals for the development of multimedia instructional material.

\section{E-learning goals}

\subsection{Goals based on the limitations of our capacity}

All aspects of e-learning are important, but due to the aim of this paper, this work will focus mainly on the information processing system. Notwithstanding, the memory system, and the motivation would be taken into account as they are all interconnected. This interconnection is reflected in the goals of multimedia e-learning stated by Mayer (2014):

-Minimise extraneous processing (directing the attention to the relevant information)

-Manage essential processing (making the content accessible and understandable, taking into account the mind limitations)

-Foster generative processing (help knowledge integration by engaging the student)

This means that the instruction needs to be designed in the first place to avoid cognitive overload, leading the student to what is relevant to the instructional goal. Then, the second requirement is to design to prevent essential overload; the learner is overloaded when the material is too complicated for them to understand. Finally, if the design manages to focus learners' attention on the important things and the content is understandable for them, therefore, the cognitive capacity is available for the generative processing. The challenge here is to help the learner to engage with learning. Fostering generative processing is about motivation.

This goals are tightly related with the learning process stages previously introduced: perception, organization and integration (Mayer, 2014). Figure 5 relates those stages with e-learning goals and summarizes their implications.

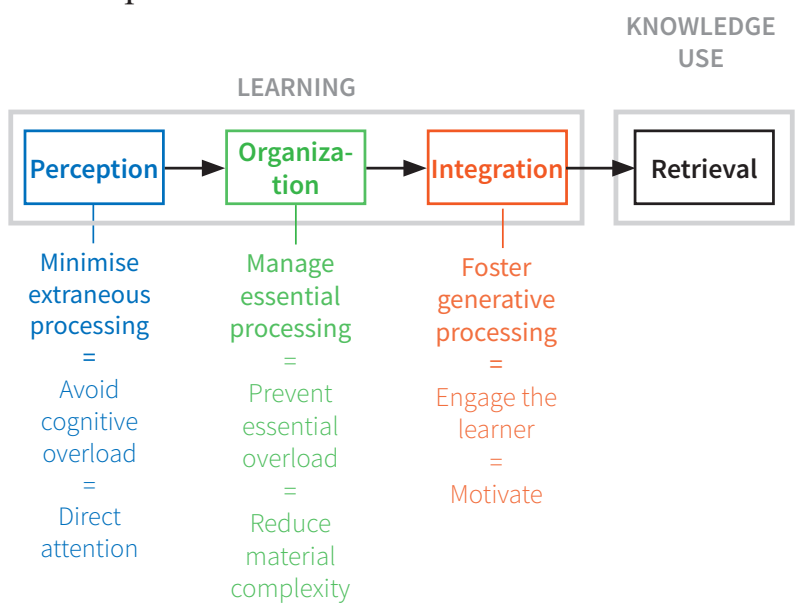

Figure 5. E-learning goals related to the learning process.

\subsection{Similarities between educational science goals and information design aims}

The design of e-learning environments is a multidisciplinary task where the design of the content to support instruction is crucial. In this literature review, it is revealed that designer can have an active role in designing for instruction. Particularly, Kazmierczak (2002) emphasises the role of designers in presenting scientific information:

"... people trained and experienced in form development and familiar with visual perception should be the ones who translate scientific structures into comprehensive visual models." (p. 186)

Designers frequently make use of research from other disciplines to aid their decision making. By handling users' characteristics and the strategies to support knowledge integration, designers can contribute to the learning experience. This shows the inherently multidisciplinary nature of design (Waller, 2011). Particularly, information design is linked to the design of instructional materials. The goal of information design was discussed by many authors. The following has been discussed:

"Information design aims at the creation of 


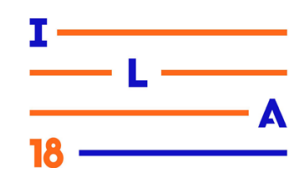

effective communications through the facilitation of the processes of perception, reading, comprehension, memorization and use of the information presented." (Frascara, 2015, p. 5)

The aim of information design provided by Frascara seems to be aligned with the goals of multimedia learning to facilitate knowledge integration:

-Minimise extraneous processing (facilitation of the process of perception)

-Manage essential processing (facilitation of the process of comprehension and memorization) -Foster generative processing (integration to memory and effective communication)

\section{How to enhance e-learning}

\subsection{Educational sciences' way to enhance e-learning}

To support the presentation of information in e-learning, learners should be guided to detect images and words that are presented in lessons; then both are organised to be incorporated into the existing memory (Clark \& Mayer, 2011). To support this process, the design of the information should be aligned with the goals of multimedia e-learning introduced before: minimise extraneous processing, manage essential processing, and foster generative processing. Cognitive sciences, psychology and behavioural sciences explain different principles to achieve these goals.

To minimise extraneous processing it is important to direct the attention and decrease unneeded processing. Signalling principle is very important in this aspect to highlight material and offer navigational support. Then, spatial and temporal contiguity principles will help learners to link related things together. Using words and picture together help people to learn deeper too (Clark \& Mayer, 2011; Mayer, 2014). Educational sciences have explained as well that simple shaped visuals for explanations help learners to pay attention to the important concepts (Kali \& Linn, 2008; Peters, 2014). Likewise, the selection of the material is important; the coherence principle states that all material that is not related to the lecture should be excluded because all extras will use precious cognitive resources. Finally, if we use both modes (written and audio) for giving the same information we will use unnecessarily working memory - redundancy principle (Clark \& Mayer, 2011; Mayer, 2014).

Reduce content complexity within the limits of our minds' capacity will help us manage essential processing. Five principles are related to this: Multimedia, modality, pre-training, segmenting and the short-term memory principle (Clark \& Mayer, 2011). The multimedia principle explains that we learn better when we present information with words and images rather than only with text; this is due to the dual channel theory, that explains that humans have two separate channels to process information and they can work at the same time. However, the modality principle suggest us to use audio instead of on-screen text in order to avoid to overloading the visual channel. Pre-training and segmenting principles are related to reducing the complexity of the information and deliver it to the learner in different stages. Finally, information must stay within our memory limits, we cannot remember seven (plus or minus two) pieces of information at a time (Horn, 1989; Clark \& Mayer, 2011; Mayer, 2014).

To integrate knowledge we need to engage learners, for that educational sciences point to our intrinsic motivation. Activating prior knowledge makes easier to integrate new thing into our long-term memory (Mayer, 2014; Loxley et al., 2013). Personalization, embodiment, voice, and storytelling principles are related to our human social capacity of interacting and make us more willing to learn. However, the image principle says that it is not necessary to include a visual character, conversational styles or descriptions will also engage the user, without extra distractions. Being in control is another thing that empowers learners and engages them with the activity (Clark \& Mayer, 2011; Druin,1999; Mayer, 2014; Wendel, 2014). Furthermore, the aesthetic-usability says that emotions affect learning, so being in a pleasant environment predispose us to learn (Norman, 2004; Peters, 2014; Wendel, 2014). Ultimately, despite dynamics visualizations seem to be very appealing, animations not necessary enhance learning. They can be distracting if they don't have a stated function like representational or directing (Mayer, 2014; Peters, 2014).

Table 2 summarizes the he principles related to support the presentation of information and their corresponding strategies to achieve each of the 
Table 2. Strategies and principles to achieve e-learning goals.

\begin{tabular}{|c|c|c|c|c|}
\hline Goal & Principle & Explanation & Strategy & References \\
\hline \multirow{6}{*}{$\begin{array}{l}\text { MINIMISE } \\
\text { EXTRANEOUS } \\
\text { PROCESSING } \\
\text { Direct attention } \\
\text { and decrease } \\
\text { extraneous } \\
\text { processing }\end{array}$} & Coherence & $\begin{array}{l}\text { People learn better when extraneous material is } \\
\text { excluded. This way they do not need to make-sense } \\
\text { or evaluate to discard information that is not important } \\
\text { to the topic. }\end{array}$ & $\begin{array}{l}\text { Add only related material } \\
\text { (audio or graphic). }\end{array}$ & $\begin{array}{l}\text { Clark \& } \\
\text { Mayer, 2011; } \\
\text { González \& } \\
\text { Salsamendi, } \\
\text { 2016; Mayer, } \\
2014\end{array}$ \\
\hline & Signalling & $\begin{array}{l}\text { People learn deeply if there are cues to highlight } \\
\text { organisation and essential material. This offers them } \\
\text { navigational support. }\end{array}$ & $\begin{array}{l}\text { Highlight essential } \\
\text { material. }\end{array}$ & $\begin{array}{l}\text { Clark \& Mayer, } \\
\text { 2011; Mayer, } \\
2014\end{array}$ \\
\hline & Redundancy & $\begin{array}{l}\text { Redundant material interferes with learning } \\
\text { because it uses working memory load for the same } \\
\text { information. }\end{array}$ & $\begin{array}{l}\text { Do not use spoken and } \\
\text { written text at the same } \\
\text { time for explanation. }\end{array}$ & $\begin{array}{l}\text { Clark \& Mayer, } \\
\text { 2011; Mayer, } \\
2014\end{array}$ \\
\hline & $\begin{array}{l}\text { Spatial } \\
\text { Contiguity }\end{array}$ & $\begin{array}{l}\text { Learning is deeper when related images and words } \\
\text { are presented near to each other. If they are not, } \\
\text { people need to use extra cognitive resources to } \\
\text { match them up. }\end{array}$ & $\begin{array}{l}\text { Position related text and } \\
\text { graphic, and words and } \\
\text { graphics near to each } \\
\text { other. }\end{array}$ & $\begin{array}{l}\text { Clark \& Mayer, } \\
2011 ; \text { Mayer, } \\
2014\end{array}$ \\
\hline & $\begin{array}{l}\text { Temporal } \\
\text { Contiguity }\end{array}$ & $\begin{array}{l}\text { Learning is deeper when related images and audio } \\
\text { are presented at the same time. If they are not people } \\
\text { need to use extra cognitive resources to match them } \\
\text { up. }\end{array}$ & $\begin{array}{l}\text { Present narration and } \\
\text { graphics simultaneously. }\end{array}$ & $\begin{array}{l}\text { Clark \& Mayer, } \\
\text { 2011; Mayer, } \\
2014\end{array}$ \\
\hline & $\begin{array}{l}\text { Simplify } \\
\text { explanatory } \\
\text { visuals }\end{array}$ & $\begin{array}{l}\text { People learn better from visuals with simplified } \\
\text { forms; they let them focus on important details. But } \\
\text { remember that children find difficult to understand } \\
\text { abstraction. }\end{array}$ & Reduce visual elements. & $\begin{array}{l}\text { Kali \& Linn, } \\
2008 ; \text { Peters, } \\
2014\end{array}$ \\
\hline \multirow{5}{*}{$\begin{array}{l}\text { MANAGE } \\
\text { ESSENTIAL } \\
\text { PROCESSING } \\
\text { Reduce content } \\
\text { complexity } \\
\text { understanding } \\
\text { mind limited } \\
\text { capacity }\end{array}$} & Multimedia & $\begin{array}{l}\text { Learning with words and images is better than } \\
\text { only with words. This is based on the dual channel } \\
\text { theory that explains that humans have two separate } \\
\text { channels to process information, and they can work } \\
\text { at the same time. }\end{array}$ & $\begin{array}{l}\text { Include words and graphics } \\
\text { rather than only words. }\end{array}$ & $\begin{array}{l}\text { Clark \& Mayer, } \\
2011 ; \text { Mayer, } \\
2014\end{array}$ \\
\hline & Modality & $\begin{array}{l}\text { Deliver words in audio instead of on-screen text can } \\
\text { generate significant learning gains. Specially if there } \\
\text { are also graphic, this way the visual channel is not } \\
\text { overload. }\end{array}$ & $\begin{array}{l}\text { Use audio rather than on- } \\
\text { screen text. }\end{array}$ & $\begin{array}{l}\text { Clark \& Mayer, } \\
2011 ; \text { Mayer, } \\
2014\end{array}$ \\
\hline & Pre-training & $\begin{array}{l}\text { The learner could be overwhelmed by the amount of } \\
\text { essential processing needed to comprehend complex } \\
\text { lessons. } \\
\text { Complicated material could be more understandable } \\
\text { by assuring the most important concepts are known } \\
\text { first. }\end{array}$ & $\begin{array}{l}\text { Introduce key concepts } \\
\text { and specific vocabulary } \\
\text { first. }\end{array}$ & $\begin{array}{l}\text { Clark \& Mayer, } \\
2011\end{array}$ \\
\hline & Segmenting & $\begin{array}{l}\text { Complex material is easy to understand if it is divided } \\
\text { into simpler comprehensible bits. }\end{array}$ & $\begin{array}{l}\text { Break a continuous } \\
\text { lesson or material into } \\
\text { manageable segments. }\end{array}$ & $\begin{array}{l}\text { Clark \& Mayer, } \\
2011\end{array}$ \\
\hline & $\begin{array}{l}\text { Limited short } \\
\text { memory }\end{array}$ & $\begin{array}{l}\text { Short memory is essential for processing information, } \\
\text { but it has a very limited capacity. We can not } \\
\text { remember more that 'Seven plus or minus two' pieces } \\
\text { of information. }\end{array}$ & $\begin{array}{l}\text { Organize information to } \\
\text { stay within memory limits: } \\
\text { - Chunk information into } \\
\text { 'Seven plus or minus two' } \\
\text {-Recode: group chunks of } \\
\text { information. }\end{array}$ & $\begin{array}{l}\text { Horn, 1989; } \\
\text { Clark \& Mayer, } \\
2011 ; \text { Mayer, } \\
2014\end{array}$ \\
\hline \multirow{2}{*}{$\begin{array}{l}\text { FOSTER } \\
\text { GENERATIVE } \\
\text { PROCESSING } \\
\text { Help knowledge } \\
\text { integration } \\
\text { by engaging } \\
\text { learners }\end{array}$} & $\begin{array}{l}\text { Personaliza- } \\
\text { tion }\end{array}$ & $\begin{array}{l}\text { People make more effort to understand material when } \\
\text { they feel they are in a conversation, rather than just } \\
\text { receiving information. }\end{array}$ & $\begin{array}{l}\text { Put words in conversation } \\
\text { style and use polite } \\
\text { speech. }\end{array}$ & $\begin{array}{l}\text { Clark \& Mayer, } \\
\text { 2011; Mayer, } \\
\text { 2014; Wendel, } \\
2014\end{array}$ \\
\hline & Voice & $\begin{array}{l}\text { People learn deeper when words are presented with } \\
\text { human voice rather than a machine one. }\end{array}$ & $\begin{array}{l}\text { Use human voice for audio } \\
\text { narrations. }\end{array}$ & $\begin{array}{l}\text { Clark \& Mayer, } \\
2011 ; \text { Mayer, } \\
2014\end{array}$ \\
\hline
\end{tabular}




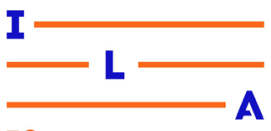

\begin{tabular}{|c|c|c|c|c|}
\hline Goal & Principle & Explanation & Strategy & References \\
\hline & Embodiment & $\begin{array}{l}\text { People learn better when pedagogical agents (virtual } \\
\text { coaches or characters) have human attributes, } \\
\text { because they feel identified. }\end{array}$ & $\begin{array}{l}\text { Use human characteristics } \\
\text { for characters, better if } \\
\text { they are similar to learners. }\end{array}$ & $\begin{array}{l}\text { Clark \& Mayer, } \\
\text { 2011; Mayer, } \\
\text { 2014; Wendel, } \\
2014\end{array}$ \\
\hline & Image & $\begin{array}{l}\text { People do not necessary learn better when the } \\
\text { speaker is on screen; but children prefer it. }\end{array}$ & $\begin{array}{l}\text { Not necessary to include a } \\
\text { visual character. }\end{array}$ & $\begin{array}{l}\text { Druin,1999; } \\
\text { Mayer, 2014; }\end{array}$ \\
\hline & Storytelling & $\begin{array}{l}\text { Story format is known by people and we are naturally } \\
\text { engaged with them. }\end{array}$ & Use storytelling. & Wendel, 2014 \\
\hline & $\begin{array}{l}\text { Learner } \\
\text { control }\end{array}$ & $\begin{array}{l}\text { The control over the learning experience depends on } \\
\text { the prior knowledge of the learner. Novice learners } \\
\text { are sometimes not mature enough to make wise } \\
\text { control decisions; they also need some more time to } \\
\text { acquire knowledge. }\end{array}$ & $\begin{array}{l}\text { Promote self-pacing } \\
\text { control specially for novice } \\
\text { learners. }\end{array}$ & $\begin{array}{l}\text { Clark \& } \\
\text { Mayer, 2011; } \\
\text { Druin,1999; } \\
\text { Mayer, 2014 }\end{array}$ \\
\hline & $\begin{array}{l}\text { Prior- } \\
\text { Knowledge } \\
\text { activation }\end{array}$ & $\begin{array}{l}\text { The activation of prior knowledge has positive effects } \\
\text { on learning, as knowledge is integrated into long term } \\
\text { memory. }\end{array}$ & $\begin{array}{l}\text { Activate prior knowledge } \\
\text { first; make children think } \\
\text { about what they already } \\
\text { know about the topic. }\end{array}$ & $\begin{array}{l}\text { Mayer, 2014; } \\
\text { Loxley et al., } \\
2013\end{array}$ \\
\hline & $\begin{array}{l}\text { Dynamic } \\
\text { visualisation }\end{array}$ & $\begin{array}{l}\text { Not necessarily animations enhance learning more } \\
\text { than static pictures. }\end{array}$ & $\begin{array}{l}\text { State the function of the } \\
\text { animation (representational } \\
\text { or directing function). }\end{array}$ & $\begin{array}{l}\text { Mayer, 2014; } \\
\text { Peters, } 2014\end{array}$ \\
\hline & $\begin{array}{l}\text { Aesthetic- } \\
\text { usability }\end{array}$ & $\begin{array}{l}\text { Aesthetics affect emotions and emotions affect } \\
\text { learning. }\end{array}$ & $\begin{array}{l}\text { Make the content } \\
\text { aesthetically pleasant for } \\
\text { your learner. }\end{array}$ & $\begin{array}{l}\text { Norman, } \\
\text { 2004; Peters, } \\
\text { 2014; Wendel, } \\
2014\end{array}$ \\
\hline
\end{tabular}

multimedia e-learning goals. This principles and strategies are mentioned by different authors, therefore referenced in the table.

\subsection{Design techniques to support e-learning strategies}

In this context, it seems interesting to explore and analyse how designers can aid multimedia learning aims. Information designers had developed through practice and research some techniques that can help to implement those learning sciences' strategies.

For example, to minimise extraneous processing and avoid overload, the learning sciences propose to direct the attention of the learner to the instructional material. To do so, based on the signalling principle already introduced, they suggest highlighting essential material. Designers have developed different strategies for this. For example: Typography differentiation, type hierarchy, space structured text, the use of pointed words, content structure, or visual hierarchy (Bertin, 2011; Frascara, 2015; Hartley, 1994;Horn, 1989; Peters, 2014; Twyman, 1981/85; van Leeuwen, 2006; Waller, 1991/2011). These examples are visualized in Figure 6.

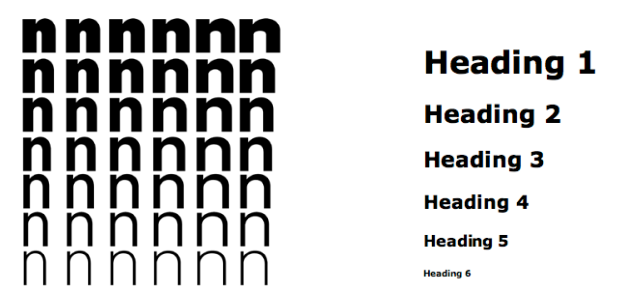

Typography differentiation

Typographic styles - Type hierarchy


Space structured text

\section{because,}

so, then, first...

\section{Pointed words}

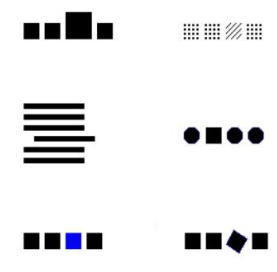

Visual hierarchy

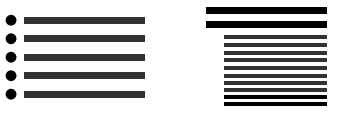

Content structure

Figure 6. Design techniques used to highlight material.

Table 3 identifies many commonly used design techniques that can be used to enhance e-learning. The table shows learning principles and strategies proposed by the learning sciences that have specific instructional goals, and then possible design 
techniques supported by authors in the design field to achieve those purposes. It is the result of the exercise of crossing the e-learning literature review presented with information design literature.

Table 3. Strategies to enhance learning supported by design techniques

\begin{tabular}{|c|c|c|c|}
\hline Goal & Principle and strategy & Design techniques & Reference \\
\hline \multirow{12}{*}{$\begin{array}{l}\text { MINIMIZE } \\
\text { EXTRANE- } \\
\text { OUS PRO- } \\
\text { CESSING } \\
\text { Direct } \\
\text { attention and } \\
\text { decrease } \\
\text { extraneous } \\
\text { processing }\end{array}$} & \multirow{3}{*}{$\begin{array}{l}\text { Coherence } \\
\text { Add only related material } \\
\text { (audio or graphic) }\end{array}$} & Make information clear without embellishments. & Frascara, 2015 \\
\hline & & $\begin{array}{l}\text { Isotype method everything should be meaningful in their } \\
\text { illustrations. }\end{array}$ & Neurath, 1936 \\
\hline & & $\begin{array}{l}\text { Relevance Principle "Include in one chunk, only information } \\
\text { that relates to one main point based on that information's } \\
\text { purpose or function for the reader". }\end{array}$ & Horn, 1989 \\
\hline & \multirow[t]{5}{*}{$\begin{array}{l}\text { Signalling } \\
\text { Highlight essential } \\
\text { material }\end{array}$} & $\begin{array}{l}\text { Typography differentiation (weight, slope, expansion (height } \\
\text { and width), curvature, connectivity, orientation, regularity, } \\
\text { size, colour, upper and lower case, letter-spacing). }\end{array}$ & $\begin{array}{l}\text { Frascara, 2015; van } \\
\text { Leeuwen, 2006; Waller, } \\
1991\end{array}$ \\
\hline & & Type hierarchy use of different typographic styles. & Waller, 1991 \\
\hline & & $\begin{array}{l}\text { Space structured text or lists to arrange text, show hierarchy } \\
\text { and convey meaning. }\end{array}$ & $\begin{array}{l}\text { Hartley, 1994; Twyman, } \\
\text { 1981; Waller, } 1991\end{array}$ \\
\hline & & $\begin{array}{l}\text { Visual hierarchy use of size, shape, texture, directionality, } \\
\text { depth, movement, colour or luminescence to achieve } \\
\text { differentiation and grab attention. }\end{array}$ & $\begin{array}{l}\text { Bertin, 2011; Twyman, } \\
\text { 1985; Peters, } 2014\end{array}$ \\
\hline & & $\begin{array}{l}\text { Pointed words such as because, so, then, first, etc. for } \\
\text { 'easyfication' of the text and content structure such as } \\
\text { introductions and conclusions, content lists, etc. }\end{array}$ & Horn, 1989; Waller, 2011 \\
\hline & $\begin{array}{l}\text { Redundancy } \\
\text { Spoken and written text }\end{array}$ & ---- & - \\
\hline & \multirow{3}{*}{$\begin{array}{l}\text { Spatial Contiguity } \\
\text { Position related text and } \\
\text { graphic, and words and } \\
\text { graphics near to each } \\
\text { other }\end{array}$} & $\begin{array}{l}\text { Gestalt principles continuation, proximity, similarity, closure, and } \\
\text { figure strengths. }\end{array}$ & $\begin{array}{l}\text { Koffka, 1935/50; Peters, } \\
2014\end{array}$ \\
\hline & & Use of labels and captions based on Gestalt principles. & Peters, 2014 \\
\hline & & Graphics and running text composition. & $\begin{array}{l}\text { Kress \& Van Leeuwen } \\
\text { 2006; Hartley, } 1994\end{array}$ \\
\hline
\end{tabular}

Temporal Contiguity

Narration and graphics

together

\section{Simplification}

Reduce visual elements, things out.
careful that children have

difficulties with abstract

concepts

Thoughtful reduction or minimalism, taking the unnecessary Carroll, 1990; Peters, 2014

Use of pictograms and simple representations (line drawings, Frascara, 2015; Peters,

silhouettes). 2014

Isotype principles usage of clear and simple graphics. Neurath, 1936

Hide or make things not visible initially (use of hover, layers, Peters, 2014 expand/collapse, tabs,etc.)

\begin{tabular}{|c|c|c|c|}
\hline \multirow{2}{*}{$\begin{array}{l}\text { MANAGE } \\
\text { ESSENTIAL } \\
\text { PROCESS- } \\
\text { ING } \\
\text { Reduce }\end{array}$} & \multirow{2}{*}{$\begin{array}{l}\text { Multimedia } \\
\text { Include words and } \\
\text { graphics rather than only } \\
\text { words }\end{array}$} & Visualisations images can summarise much information. & Tufte, 1990 \\
\hline & & $\begin{array}{l}\text { Isotype principles visual education could enhance learning } \\
\text { and teaching in schools. Usage of many used many different } \\
\text { methods of visual representation. }\end{array}$ & $\begin{array}{l}\text { Burke, Kindel and Walker, } \\
2013\end{array}$ \\
\hline
\end{tabular}

ING words

Reduce

content com-

plexity un-

derstanding

mind limited capacity

\section{Modality}

Use audio rather than on-

screen text

\section{Pre-training}

Key concepts and vocabulary first

\section{Segmenting}

Break a continuous lesson or material into manageable segments

imited short memory Organize information to stay within memory limits
Use of chunks and blocks of information Chunks are Hartley, 1994; Peters,

Different type of graphics representational, relational, 2014; Twyman, 1985 things that otherwise are invisible. small and processable pieces of information and blocks is information laid out in a consistent way.

\begin{tabular}{ll}
$\begin{array}{l}\text { Sequencing and segmenting to avoid introducing all the } \\
\text { information at once. }\end{array}$ & $\begin{array}{l}\text { Norman \& Spohrer, 1996; } \\
\text { Peters, 2014 }\end{array}$ \\
\hline $\begin{array}{l}\text { Interactive layers use of layers to access to more information. } \\
\text { Use of chunks and blocks of information Chunks are }\end{array}$ & Horn, 1989; Murray, 2012 \\
$\begin{array}{l}\text { Small and processable pieces of information and blocks is } \\
\text { information laid out in a consistent way. }\end{array}$ &
\end{tabular}




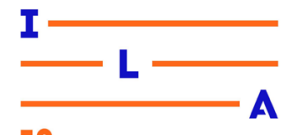

\begin{tabular}{|c|c|c|c|}
\hline Goal & Principle and strategy & Design techniques & Reference \\
\hline \multirow{11}{*}{$\begin{array}{l}\text { FOSTER } \\
\text { GENERA- } \\
\text { TIVE PRO- } \\
\text { CESSING } \\
\text { Help } \\
\text { knowledge } \\
\text { integration } \\
\text { by engaging } \\
\text { learners }\end{array}$} & $\begin{array}{l}\text { Personalization } \\
\text { User conversational style }\end{array}$ & --- & - \\
\hline & $\begin{array}{l}\text { Voice } \\
\text { Use human voice }\end{array}$ & --- & - \\
\hline & $\begin{array}{l}\text { Embodiment } \\
\text { Human like characters }\end{array}$ & --- & - \\
\hline & $\begin{array}{l}\text { Image } \\
\text { No need for a visual } \\
\text { character }\end{array}$ & --- & - \\
\hline & \multirow{2}{*}{$\begin{array}{l}\text { Storytelling } \\
\text { Use storytelling }\end{array}$} & Narration. & Wendel, 2014 \\
\hline & & $\begin{array}{l}\text { Narrative representations graphics, storyboards, movies, } \\
\text { animations, etc. }\end{array}$ & $\begin{array}{l}\text { Kress \& van Leeuwen, } \\
\text { 2006; Twyman, } 1985\end{array}$ \\
\hline & $\begin{array}{l}\text { Learner control } \\
\text { Promote self pacing } \\
\text { control }\end{array}$ & $\begin{array}{l}\text { Include noticeable controls to navigate the content, allowing } \\
\text { the user to control his time with the information. }\end{array}$ & Peters, 2014 \\
\hline & $\begin{array}{l}\text { Prior-Knowledge } \\
\text { activation } \\
\text { Activate prior knowledge } \\
\text { first. }\end{array}$ & --- & - \\
\hline & Dynamic visualisation & --- & - \\
\hline & \multirow{2}{*}{$\begin{array}{l}\text { Aesthetic-usability } \\
\text { Aesthetically pleasant for } \\
\text { your learner }\end{array}$} & $\begin{array}{l}\text { User-centred design know your user to know what he likes by } \\
\text { applying user research methods. }\end{array}$ & $\begin{array}{l}\text { Garrett, 2011; Norman, } \\
1990\end{array}$ \\
\hline & & Harmony and proportion design elements fitting well together. & $\begin{array}{l}\text { Pettersson, 2002; Norman, } \\
1990\end{array}$ \\
\hline
\end{tabular}

\subsection{Design techniques application at different levels}

The design techniques presented support educational sciences' strategies for knowledge acquisition. They can be applied on different levels - on a micro, macro and meta level. The micro level is related to the components of the design, while the macro level is the content structure, this means the relationship between the components. Finally, the meta level describes the principles behind the design (Gillieson, 2008). Figure 7 represents and provide examples at these three levels.



Figure 7. Design levels.

The following matrix (Table 4) intends to organize and arrange design techniques into these levels.

Table 4. Design techniques to reach e-learning goals on different levels

\begin{tabular}{|c|c|c|c|c|}
\hline Goal & Principle & Micro level techniques & Macro level techniques & Meta level techniques \\
\hline $\begin{array}{l}\text { MINIMIZE } \\
\text { EXTRANE- } \\
\text { OUS PRO- } \\
\text { CESSING } \\
\text { Direct } \\
\text { attention and } \\
\text { decrease } \\
\text { extraneous } \\
\text { processing }\end{array}$ & Coherence & - Isotype method & & $\begin{array}{l}\text { - Relevance Principle } \\
\text { - Isotype method }\end{array}$ \\
\hline
\end{tabular}

\begin{tabular}{|c|c|c|c|}
\hline Signalling & $\begin{array}{l}\text { - Typography differentiation } \\
\text { - Visual hierarchy } \\
\text { - Pointed words } \\
\text { - Pointed elements } \\
\text { - Attention grabbers }\end{array}$ & $\begin{array}{l}\text { - Typography styles } \\
\text { - Type hierarchy } \\
\text { - Space structured text } \\
\text { - Visual hierarchy } \\
\text { - Content structure }\end{array}$ & - Access structure \\
\hline
\end{tabular}




\begin{tabular}{|c|c|c|c|c|}
\hline & \multicolumn{2}{|l|}{ Redundancy } & \multicolumn{2}{|l|}{$\begin{array}{l}\text { - No spoken and written text } \\
\text { simultaneously }\end{array}$} \\
\hline & Spatial Contiguity & $\begin{array}{l}\text { - Use of Labels } \\
\text { - Gestalt principles }\end{array}$ & $\begin{array}{l}\text { - Use of Captions } \\
\text { - Text/graphic relations } \\
\text { - Gestalt principles }\end{array}$ & \\
\hline & Temporal Contiguity & & $\begin{array}{l}\text { - Narration and graphics } \\
\text { simultaneously }\end{array}$ & \\
\hline & Simplification & $\begin{array}{l}\text { - Thoughtful reduction } \\
\text { - Simple representations and } \\
\text { forms } \\
\text { - Isotype principles } \\
\text { - Background elimination }\end{array}$ & $\begin{array}{l}\text { - Layers of information } \\
\text { - Interactive layers } \\
\text { - Clear backgrounds } \\
\text { - Low granularity and density }\end{array}$ & $\begin{array}{l}\text { - Use of pictograms } \\
\text { - Selection of material } \\
\text { according to learner's } \\
\text { knowledge }\end{array}$ \\
\hline & Consistency & $\begin{array}{l}\text { - Use of styles } \\
\text { - Labelling }\end{array}$ & $\begin{array}{l}\text { - Use of grid or consistent } \\
\text { layout }\end{array}$ & - Being predictable \\
\hline & Comfortable reading & $\begin{array}{l}\text { - Typography settings } \\
\text { - Legibility }\end{array}$ & $\begin{array}{l}\text { - Text/graphic relations } \\
\text { - Text layout } \\
\text { - Typography styles } \\
\text { - Type hierarchy }\end{array}$ & $\begin{array}{l}\text { - Readability } \\
\text { - Use of relevant } \\
\text { vocabulary and syntax }\end{array}$ \\
\hline \multirow{5}{*}{$\begin{array}{l}\text { MANAGE } \\
\text { ESSENTIAL } \\
\text { PROCESS- } \\
\text { ING } \\
\text { Reduce } \\
\text { content com- } \\
\text { plexity un- } \\
\text { derstanding } \\
\text { mind limited } \\
\text { capacity }\end{array}$} & Multimedia & $\begin{array}{l}\text { - Use of Labels } \\
\text { - No abstract images }\end{array}$ & $\begin{array}{l}\text { - Use of Captions } \\
\text { - Different type of graphics }\end{array}$ & $\begin{array}{l}\text { - Use of Visualisations } \\
\text { - Isotype principles } \\
\text { - Different type of graphics }\end{array}$ \\
\hline & Modality & $\begin{array}{l}\text { - Use audio rather than on- } \\
\text { screen text }\end{array}$ & & \\
\hline & Pre-training & & & $\begin{array}{l}\text { - Content structure } \\
\text { - Product structure }\end{array}$ \\
\hline & Segmenting & $\begin{array}{l}\text { - Chunks and Blocks of information } \\
\text { - Sequencing and segmenting }\end{array}$ & - Interactive layers & $\begin{array}{l}\text { - Chunks and Blocks of } \\
\text { information } \\
\text { - Sequencing and } \\
\text { segmenting }\end{array}$ \\
\hline & $\begin{array}{l}\text { Limited short } \\
\text { memory }\end{array}$ & $\begin{array}{l}\text { - Chunks and Blocks of } \\
\text { information }\end{array}$ & & $\begin{array}{l}\text { - Chunks and Blocks of } \\
\text { information } \\
\text { - Repetition } \\
\text { - Content structure } \\
\text { (summaries, key facts) }\end{array}$ \\
\hline \multirow{9}{*}{$\begin{array}{l}\text { FOSTER } \\
\text { GENERA- } \\
\text { TIVE PRO- } \\
\text { CESSING } \\
\text { Help } \\
\text { knowledge } \\
\text { integration } \\
\text { by engaging } \\
\text { learners }\end{array}$} & Personalization & $\begin{array}{l}\text { - Conversational text style } \\
\text { - Balloon dialogue } \\
\text { representations }\end{array}$ & & $\begin{array}{l}\text { - Appropriate text style } \\
\text { - Use of dialogues } \\
\text { - User centred design }\end{array}$ \\
\hline & Voice & $\begin{array}{l}\text { - Use human voice for audio } \\
\text { narrations }\end{array}$ & & \\
\hline & Embodiment & $\begin{array}{l}\text { - Use human characteristics for } \\
\text { characters }\end{array}$ & & $\begin{array}{l}\text { - Characters similar to } \\
\text { learners } \\
\text { - User centred design }\end{array}$ \\
\hline & Image & & & $\begin{array}{l}\text { - Children like on-screen } \\
\text { characters }\end{array}$ \\
\hline & Storytelling & $\begin{array}{l}\text { - Narrative representations } \\
\text { - Narrations }\end{array}$ & & $\begin{array}{l}\text { - Use a story or familiar } \\
\text { situation as a thread } \\
\text { - Content structure } \\
\text { - Product structure }\end{array}$ \\
\hline & Learner control & - Clear Controls & & - Give self-pacing control \\
\hline & $\begin{array}{l}\text { Prior-Knowledge } \\
\text { activation }\end{array}$ & - Questions, familiar situations & & $\begin{array}{l}\text { - Start introduction } \\
\text { retrieving their prior } \\
\text { knowledge }\end{array}$ \\
\hline & $\begin{array}{l}\text { Dynamic } \\
\text { visualisation }\end{array}$ & & $\begin{array}{l}\text { - State the function (title, } \\
\text { caption) }\end{array}$ & \\
\hline & Aesthetic-usability & $\begin{array}{l}\text { - Harmony } \\
\text { - Proportion } \\
\text { - Appealing graphics } \\
\text { - Pleasant type setting }\end{array}$ & $\begin{array}{l}\text { - Harmony } \\
\text { - Proportion } \\
\text { - Composition } \\
\text { - Use of grid }\end{array}$ & $\begin{array}{l}\text { - User centred design } \\
\text { - Testing }\end{array}$ \\
\hline
\end{tabular}




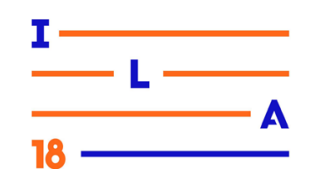

This matrix can be utilised either as a tool for design or as a tool for analysis. For teams designing e-learning instructional experiences, the matrix, as well as the literature review, serves as a summary of the relevant matters to design instruction in multimedia environments. To plan the principles and structure of the environment, designers can use the design techniques and strategies on a meta level. For the actual design and display of information onscreen, the techniques on a micro and macro level will help to achieve the e-learning objectives.

The table can also serve as an analysis tool too. It is not intended as a checklist because not all the strategies need to be applied. However, it can be used to improve current environments by checking which strategies are used, which were consciously avoided and to reflect on which ones can be introduced or applied further.

\section{Conclusions}

Knowledge generated by the educational sciences (Psychology, cognitive and behavioural sciences) could be used by designers to improve the design of e-learning instruction. This paper introduced the learning process as a multi-modal one, which uses perception through more than one channel-aural or visual. Particularly, graphic designers are specialized in the visual channel were more than one mode of information is delivered. Making them useful professionals for the development of instructional material.

There are specific educational goals to achieve in each learning stage. These goals are related to our limited capacity as human beings to process information. The learning sciences introduce different principles that explain how our brains work; consequently, they also introduce specific strategies to reach the instructional goals. They suggest that it is important to direct attention to the instructional information to avoid cognitive overload. It is also important to reduce the complexity of the material and to engage the learner by motivating him or her.

Information designers share educational sciences' strategies. Further, the aim of the discipline is tightly aligned with the educational goals proposed to enhance learning. In this regard seems that one discipline is able to help the other one to reach a common objective.

Designers through practice and research have generated many design techniques that can be used to reach the strategies proposed by the learning sciences. Taking into account these strategies, design efforts can be focused and guided to enhance learning. This paper has introduced a matrix in table 4 that summarises many of the design techniques documented, to help designers to address learners' needs at different levels.

\section{Bibliographic references}

\subsection{Works cited}

Bertin, J. (2011). Semiology of graphics: diagrams, networks, maps. Redlands, California: Esri Press.

Burke C., Kindel E. \& Walker S. (2013). Isotype, design and contexts 1925-1971. London: Hyphen Press.

Byrne, J. \& Sharp, J. (2002). Using ICT in primary science teaching. Exeter: Learning Matters. CEP, A. República Oriental del Uruguay (2009). Programa de Educación Inicial y Primaria. Año 2008.

Clark, R. \& Mayer, R. (2011). E-learning and the science of instruction. San Francisco, CA: Pfeiffer. Frascara, J. (2015) Information design as principled action: Making information accessible, relevant, understandable, and usable. USA: Common Ground Publishing LLC.

Garrett, J. J. (2010). Elements of user experience, the: user-centered design for the web and beyond. Pearson Education.

González, M. \& Salsamendi, A. (2016). Comunicación multimodal en Ciencias Naturales: un análisis a partir de propuestas de enseñanza del libro de cuarto año de Educación Primaria. (Master) Facultad de Humanidades y Ciencias de la Educación, UDELAR.

Hartley, J. (2013). Designing instructional text. Routledge.

Hsi, S. \& Soloway, E. (1998). Learner-centered design: specifically addressing the needs of learners. SIGCHI Bull., (Vol. 30, No. 4, pp. 53-55). http:// dx.doi.org/10.1145/310307.310374

Horn, R. E. (1989). Mapping hypertext. The Lexington Institute of Hospitality Careers. 

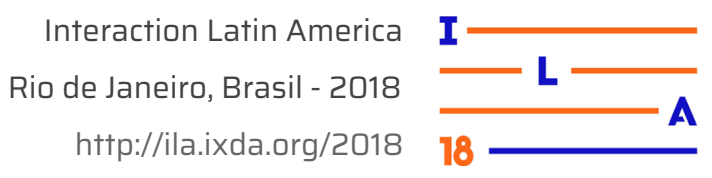

Kazmierczak, E. T. (2001). A semiotic perspective on aesthetic preferences, visual literacy, and information design. Information Design Journal, (Vol. 10, No. 2, p. 176-187).

Kress, G., \& Van Leeuwen, T. (2006). Reading images: The grammar of visual images.

Mason, R. \& Rennie, F. (2006). Elearning: The key concepts. London: Routledge.

Mayer, R. (2014). The Cambridge Handbook of Multimedia Learning (2nd ed.). Cambridge University Press.

Murray, J H (2012) Inventing the medium: principles of interaction design as a cultural practice (pp.223-251). Cambridge, Mass.: MIT Press Neurath, O. (1936). International Picture Language. The first rules of Isotype: With Isotype pictures. London: Kegan Paul \& Co.

Norman, D. (2004). Emotional design: Why we love (or hate) everyday things. New York: Basic Books.

Norman, D. \& Spohrer, J. (1996). Learner-centered education. Communications Of The ACM, (Vol. 39, No. 4, pp. 24-27). http://dx.doi. org $/ 10.1145 / 227210.227215$

One laptop per child,. (2016). About us. one laptop per child. Retrieved 11 June 2016, from http://one. laptop.org/about

Peters, D. (2014). Interface design for learning:

Design strategies for learning experiences. Pearson Education.

Pettersson, R (2002) Information design: an introduction. Amsterdam: John Benjamins

tional design: Making learning design a reality. In JLD, (Vol. 1, No. 2). http://dx.doi.org/10.5204/jld. v1i2.11

Tufte, E. R. (1990). Envisioning information.

Cheshire, Connecticut: Graphics Press

Twyman, M. (1979). A schema for the study of graphic language (tutorial paper). Processing Of Visible Language (pp. 117-150). Springer US.

Twyman, M. (1981). Typography without words. Visible Language, (Vol. 15, No. 1, pp. 5-12).

Twyman, M. L. (1985). Using pictorial language: a discussion of the dimensions. Designing usable text, (pp. 245-312).

Van Leeuwen, T. (2006). Towards a semiotics of typography. In Information Design Journal, (Vol 14, No. 2, pp. 139-155).

Waller, R. H. W. (1985). Using typography to structure arguments: a critical analysis of some examples. The technology of text, (Vol 2, pp. 105-125).
Waller, R. (1991). Designing Reports and Presentations: Monotype Desktop Solutions. Monotype. Waller, R. (2011). Information design: how the disciplines work together. Simplification Centre as Technical paper. https://www.reading.ac.uk/web/ FILES/simplification/SC14DisciplinesTogether-7. pdf

Wendel, S. (2013). Designing for behavior change: Applying psychology and behavioral economics. O’Reilly Media, Inc.

\subsection{Works cited by other authors}

Carroll, J. M. (1990, January). An overview of minimalist instruction. In System Sciences, 1990., Proceedings of the Twenty-Third Annual Hawaii International Conference (Vol. 4, pp. 210-219). IEEE.

Deci, E. L., \& Ryan, R. M. (1975). Intrinsic motivation. John Wiley \& Sons, Inc..

Koffka, K. (2013). Principles of Gestalt psychology (Vol. 44). Routledge.

\section{Acknowledgements}

All formatting was done by Julia Castillo

Paper based in the dissertation for the Master of Arts in Information Design, at Reading University. Tutor: Keith Tam.

Chevening Scholarships, the UK government's global scholarship programme, funded by the Foreign and Commonwealth Office (FCO) and ANII. 